\title{
Linguistic peculiarities of feminine and masculine political media discourse in English-speaking countries
}

\author{
Tatyana G. Popova - Yelena V. Sausheva - Tatyana I. Surikova - Rozaliya \\ R. Yusupova - Anna I. Dzyubenko
}

DOI: 10.18355/XL.2018.11.02.12

\begin{abstract}
The article presents the results of the research of linguistic peculiarities of political media discourse in English-speaking countries. Special attention the article pays to feminine and masculine features of political media discourse. In the article, we establish that the common linguistic features of masculine and feminine political media discourse include frequent use of the superlative and comparative degrees of adjectives; active voice prevailing over passive, the low frequency of conjunctionless subordinate clauses; active use of stylistic devices. We describe masculine political media discourse, which is characterized by the predominance of negatively colored lexical units, the frequent use of words with negative prefixes, the variety of linking words. We can see that feminine political media discourse is marked by the high frequency of words denoting different emotional states, the use of expressive phrases, the use of words with a modal meaning, expressing obligation, doubt, uncertainty, probability.
\end{abstract}

Key words: mass media, political media discourse, linguistic peculiarities, feminine and masculine features, English-speaking countries

\section{Introduction}

Politics since the birth of human relations up to the present has been playing a big role in the life of any person. It is no accident that the political sphere is one of the structural components of society (along with the economic, social, spiritual). The position of the country in the overall ranking of the world powers, its relations with different countries, its position in solving problems of the world community, its point of view on the solution of a particular international issue depends on the position of the leadership of the country or a certain political situation. One of the main social institutions is called the political institute. As a structural component of the political media sphere, it is a dynamic, evolving system, which representatives interact and communicate with each other. Political communication in mass media of participants in media speech interaction, using modern terminology, is called political media discourse. This process of speech interaction in a socially significant sense consists of a set of certain utterances of the speaker, taking into account the opinion of another interlocutor in politics, i.e. certain structural components between the thought and action of each participant in the dialogue in political communication.

The study of the materials of political media discourse allows, on the one hand, anticipating the actions and intentions of the politician in the future and, on the other hand, determining the best opportunities and ways of influencing the audience in order to achieve the result of speech interaction.

The linguistic research of linguistic features of the English-speaking feminine and masculine political media discourse allow making the conclusion that the scientific novelty of the study is defined by analyzing of similarities and differences in the linguistic expression of female and male politicians in modern political media discourse.

XLinguae, Volume 11, Issue 2, April 2018, ISSN 1337-8384, eISSN 2453-711X 


\subsection{Theoretical Research Base: Condition of Problem's Study}

From the standpoint of psycholinguistics, political communication is seen as a process of verbal and nonverbal speech, taking into account the psychological characteristics of the participants of communication, social role-playing attitudes, norms, and requirements (Zheltukhina, 2003, Zheltukhina et al., 2017a; Zheltukhina et al., 2017b). The emphasis is on the analysis of speech errors in the process of communication.

The social conditions for the implementation of speech acts presuppose the definition of their features, due to the use of different social status of people who make up the language community. Depending on the membership of the social group, a comparative analysis of the use of means and methods of communicative interaction in certain historical conditions is carried out. Their features are determined, and general features are distinguished.

Socio-political speech is a special type of communication. It is characterized by a relatively high degree of persuasion and influence. To do this, it is necessary to identify and determine ways of political communication, and in particular, the suggestive function of the language. This is the importance and relevance, the necessity to know the socio-political speech as a means of political communication. This is dictated by the need to reach an acceptable consensus between the two sides of the communication process: on the one hand, the implementation of the function of influencing the audience, on the other - to convince the audience to understand the true intentions and hidden techniques of speech influence of the speaker.

Political media discourse is closely related to the analysis of the form, different tasks and content used in certain (in other words, "political") situations in mass media. In socio-political media speech communication is defined as institutional, which uses a certain method, pragmatic techniques, means and tools, including lexical means of expression, stylistic figures, a certain way of linking sentences in the media text (Tarde, 1969; Levinson, 1983; Mann, Matthiessen, Thompson, 1992; Thompson, 1995; Marcu, 1996; Jamieson, Campbell, 1997; Jacobson, 2000; Witosh, 2005; Olyanich, 2007; Issers, 2008; Heuboeck, 2009; Pavlic, 2009; Popova, 2014; Sausheva, 2017; Surikova, 2017; Yusupova, Teplyh, 2017; Zhetukhina et al., 2017a,b; Gulinov et al., 2018). It is considered that political media discourse as a form of political media speech interaction has a number of distinctive characteristics:

- the use in speech interaction of specific terms, concepts, sometimes not always understandable to the majority of the audience);

- special components of the position of this phenomenon (the result - the use of not always standard speech methods, methods and techniques);

- special implementation of discourse, its auditory or visual design.

Usually, the agent of verbal political interaction seeks to:

a) convince the addressee to vote for a certain representative of a political party, a candidate in elections of various levels or referendums;

b) increase the assessment of their activities in the eyes of others, "be to the people's liking", "to draw attention";

c) support the views, opinions, and assessment of the speaker's events;

d) contribute to the creation of a certain psycho-emotional state of the listener;

Among scientists engaged in the study and analysis of political discourse, there is no generally accepted definition. In the specialized scientific-journalistic literature its various synonymous of interpretation are used, namely "public political speech" (Yudina, 2001), political language, electoral politics, political debate, etc.

Linguists explain the meaning of political discourse using different semantic characteristics. In a broad sense, a social and historical phenomenon pervades every age of history (Sheigal, 2003). These are political power relations in all their manifestations (Gerasimenko, 2002). It is a set of different tools and techniques of 
professional activities as experts for whom politics is a profession, and the citizens (Baranov, 2003). At the same time, in support of our definitions, we used and analyzed the speeches of the leaders of states, politicians, leaders of socio-political movements and associations, publications in the media and the Internet, as well as materials of specialized scientific thematic publications on various issues of politics in general, and political speech communication in particular as political speech (language) material. With this explanation, the analysis of the socio-political media speech seems to be the most complex.

Interest in the study and analysis of political discourse has led to the emergence of science engaged in establishing the mutual influence of socio-political events on changes in the language. A.N. Baranov (2003) identifies several factors that contribute to the analysis of political texts (speeches, appeals, publications):

1. The internal needs of the science itself, which shows a steady interest in the study of verbal communication in different historical eras;

2. Features of political interaction in the sphere of communication, the study of the specifics of thinking and possible construction of a model of behavior in the political sphere of public figures, the analysis of their activities in order to monitor the various directions of development of public consciousness;

3. Public order.

Other researchers suggest considering political discourse as a language of social life. Other authors who study this phenomenon believe that the political component is present in virtually all public performances in a variety of forms (citations, hearings, speeches, appeals). Therefore, social and political communication is always a popular use of language in the political media communicative sphere in reality. We can determine many factors:

1. Theme of the text.

2. The content of the text.

3. Use of this text (its importance and scope) in political media communication. The totality of all speech acts used in socio-political activity takes into account the growing influence of the human consciousness of mass media, television, the Internet (Politically speaking, 1998).

As already mentioned, the activity of politicians is a "mirror" of the struggle for power at various levels. This determines the peculiarities of communicative methods and techniques, the basis of which is the desire to have an impact on the mental, psychological, emotional sides of the participants of communicative interaction (i.e. on the audience). Inviting-incentive function of speech acts in political communication is achieved using techniques and methods of political media communication.

\section{Methodological Bases and Research Methods}

The purpose and problems of our research cause the following methods of our analysis: deductive, inductive, descriptive and comparative methods. The theoretical approach is based on the analyticity and publicity in political linguistics, media linguistics, and linguopragmatics. The linguosemantic and linguostylistic analyses can help to reveal linguistic peculiarities of feminine and masculine political media discourse in English-speaking countries.

Lexical and stylistic characteristics of political media communication focus our attention, first, on the theme, idea, form, expressed in style, type, composition of public speech of the politician. It implies an analysis of the use of lexical means of expression, stylistic figures, and the syntactic structure of the media speech of politicians or other participants in political media communication.

Knowing the lexical and stylistic features, taking into account the national peculiarities and characteristics of a certain ethnos or nation, it is possible to

XLinguae, Volume 11, Issue 2, April 2018, ISSN 1337-8384, eISSN 2453-711X 
determine the generally accepted patterns of behavior in the process of implementing speech acts of political media interaction in general and to characterize the cultural priorities of the corresponding national historical community.

\section{Results and Discussion}

After analyzing the speeches of political figures of Great Britain and America, we have concluded that there are linguistic features inherent in political media discourse. The study also revealed some gender preferences of politicians in the choice of vocabulary, grammar, and stylistic devices.

1. The analysis of the texts of speeches of politicians of both sexes allows classifying the following features as common for masculine and feminine political media discourse:

- Appealing to concepts that are fundamental in a democratic society (freedom, law, democracy, right, equality, justice):

"Their cause, at its core, however, is not about the pursuit of values that we can relate to; but in pursuit of values that directly contradict our way of life. They don't believe in democracy, equality or freedom" (Meyers, 2009).

"As article $100 \mathrm{~A}$ makes clear, qualified majority voting does not apply "to fiscal provisions, to those relating to the free movement of persons nor to those relating to the rights and interests of employed persons"" (Thatcher, 1991).

These concepts are "sacred formulas" for every citizen of his country. This is their peculiarity and frequency of use in a political dialogue. In addition, speakers use them in order to justify their actions in front of the community.

- Frequent use of the superlative and comparative degree of adjectives, adding expressiveness to the statements of politicians:

" As for me, I am older, better educated by the events that shaped my premiership, but I still believe that those who oppress and brutalize their citizens are better put out of power than kept in it" (Meyers, 2009).

The lexical features of the political media discourse of male politicians include the following:

- The predominance of negatively colored lexical units (such as ailure, disaster, ruin etc.):

"But the failure to respond is a direct result of a broken politics in Washington and the failed policies of George W. Bush" (Obama, 2008).

Male politicians use these words if they need to discredit another candidate's policy.

- Frequent use of words with negative prefixes un-, dis-, il-, im-, in-, ir-:

"The notion of humanitarian intervention was the meddling of the unwise, untutored and inexperienced" (Meyers, 2009).

- The use of the word war and semantically related lexical units, such as sword, death, army:

"The Civil War was one of the bloodiest in history, and yet it was only through the crucible of the sword, the sacrifice of multitudes, that we could begin to perfect this union, and drive the scourge of slavery from our soil. I don't oppose all wars" (Obama, 2009b).

- The variety of linking words: since, as, moreover, thus, therefore, consequently, however, nevertheless:

"Secondly, there is some good news. Ultimately, this battle can only be won within Islam itself and the fact is, across Islam today, we have allies ... However, I do not accept at all the view that democracy is unattainable or unaccepted in the Islamic world" (Meyers, 2009).

Linking words make the speech of a politician more coherent and add some expressiveness to it.

2. The lexical features of feminine political media discourse include the following: 
- Frequent use of the words hope, believe, feel glad, love, frustrated, doubt, worry, denoting different emotional states:

"I still believe Trump is 'a clear and present danger to America'" (Clinton, 2017).

This vocabulary helps to create a positive image of a politician, to bring him closer to the people.

- Use of expressive phrases (e.g., "incredibly demanding job", "very difficult problems" and so on):

"And we were deeply distressed by the bombings that took place in Tashkent and the armed incursions into Kyrgyzstan" (Albright, 2000).

Expressiveness helps to focus and draw attention of the audience to some phenomenon or event.

- Such introductory words as maybe, probably, perhaps, verb seem, modal verbs may, might, indefinite pronouns some, somewhat, somehow, someplace, phrases a kind of, a sort of and phrases some kind of, some sort of.

"Perhaps I may also say this to the noble Lord, Lord Jenkins of Hillhead: will he do me the honour of reading through the speech to the end" (Thatcher, 1993).

- Expessing the shade of obligation using modal verbs:

"But in order to achieve each of our goals in our relationship, we have to break with the past. We have to be committed to an open and honest and dialogue. We have to be very honest about our differences, and I think we've begun to establish that level of communication. And we have to find ways of working together" (Clinton, 2010).

Female politicians mainly use literary lexicon of the English language in political media communication in order to make their speech more understandable to a wide audience, they do not practically use words belonging to special colloquial vocabulary (vulgarisms, jargon), so-called obscenity. Therefore, female political media communication is characterized by literacy and correctness of speech, the use of correct and understandable vocabulary for the broad audience, the accuracy and expressiveness of the information offered.

Following the lexical ones, we have singled out the grammatical features of the masculine and feminine political media discourse. In the course of empirical and theoretical, we have come to the following conclusions:

- The prevalence of the active voice over the passive. We believe that the use of the active voice gives the speaker greater confidence.

- Low frequency of compound independent clauses. In our opinion, the addressees of the message more easily perceive sentences with coordinating and subordinate conjunctions than independent clauses.

- Lack of elliptical structures.

3. The grammatical features of the male political media discourse include the following:

- Preference is given to simple sentences:

"I never thought such politics very sensible or practical. I think it even less so now. We live in the era of interdependence..." (Meyers, 2009).

We believe that male politicians tend to be more practical and understandable for the entire target audience.

- Using compound sentences:

"We can understand the emotions generated by Northern Ireland's troubles, but we cannot really believe, as we approach the 21st century, there is not a better way forward to the future than murder, terrorism and sectarian hatred" (Blair, 1998).

The grammatical features of feminine political media discourse include:

- The predominance of complex sentences in the speech:

"I am looking forward to seeing the great centers of culture and learning when I visit Samarkand and Bukhara" (Albright, 2000).

XLinguae, Volume 11, Issue 2, April 2018, ISSN 1337-8384, eISSN 2453-711X 
- Frequent use of homogeneous parts of the sentence, which allows to focus the audience's attention on any fact:

"To make the right decisions, you have to understand local populations, local circumstances and local needs" (Albright, 2000).

4. In the material of this study, we have not revealed gender specificity in the use of stylistic devices. Thus, we have identified the following stylistic features that are common to both masculine and feminine political media discourse:

- Extensive use of metaphors:

"Our next President must work with Congress and every other willing partner across our entire country. And I will do just that -- to turn the tide so these currents start working for us more than against us" (Clinton, 2015).

"The words have been spoken during rising tides of prosperity and the still waters of peace" (Obama, 2009a).

Every politician has to resort to a number of techniques designed to arouse attention and interest in the content of speech. Metaphor makes a politician's speech more vivid and interesting for the recipient.

- Rhetorical questions:

"You want a fight, President Bush? Let's fight to wean ourselves off Middle East oil, through an energy policy that doesn't simply serve the interests of Exxon and Mobil" (Obama, 2009b).

"What part of democracy are they afraid of?" (Clinton, 2015).

Rhetorical questions attract the intensified attention of the listener, and raise the emotional tone of the utterance.

- Anaphora as a repeated repetition of a word in each parallel element of speech to enhance the imagery and expressiveness of the information offered:

"I believe you should have the right to earn paid sick days. I believe you should receive your work schedule with enough notice to arrange childcare or take college courses to get ahead. I believe you should look forward to retirement with confidence, not anxiety.

That you should have the peace of mind that your health care will be there when you need it, without breaking the bank. I believe we should offer paid family leave so no one has to choose between keeping a paycheck and caring for a new baby or a sick relative" (Clinton, 2015).

"On this day, we gather because we have chosen hope over fear, unity of purpose over conflict and discord. On this day, we come to proclaim an end to the petty grievances and false promises, the recriminations and worn out dogmas, that for far too long have strangled our politics" (Obama, 2009a).

Anaphora imparts greater credibility to the speech of the politician and allows to draw the attention of the audience to certain words and expressions.

- Hyperbole is a figure of speech, consisting in deliberate exaggeration:

"And after we've won, we're going to reach out our hand to any willing patriot, make this government start working for you again, and get this country back on the road to prosperity and peace" (Mccain, 2008).

"President Roosevelt called on every American to do his or her part, and every American answered" (Clinton, 2015).

Hyperbole, in our opinion, has a stronger effect of convincing of the utterance than other stylistic devices. It allows the politician to create a powerful image in the consciousness of the addressee, and, ultimately, manipulate people's minds.

Thus, the analysis of linguistic means used by participants in political media discourse showed that in the process of verbal influence on the consciousness of the electorate, politicians fully demonstrate their linguistic competence. For the purposes of speech impact, a wide range of linguistic devices can be used, and the effectiveness of this impact is provided by their skillful variation. 
The study revealed the main lexical and morphological, syntactic and stylistic features of the English speech statements of politicians.

We used the political pre-election speeches of $\mathrm{H}$. Clinton and B. Obama as a comparative research material in our work. Both of them have a $\mathrm{PhD}$ degree and practically the same age qualification.

At first glance, there are practically no differences in their pre-election programs. For a simple, average citizen they are invisible. One of the features of the dialogue of political interaction is that it is focused on a certain audience and the factor of the addressee has a certain influence on the choice of linguistic, stylistic, syntactic statements. The pre-election political speech of H. Clinton and B. Obama is initially planned for all those present without paying attention to their biological characteristics or political views, although the text and all material for the speech or appeal are chosen for a particular audience.

In accordance with the analysis, in our opinion, there are no clear differences in the performance of politicians based on biological sign on the morphological level of the language. As a result of the analysis and comparison of quantitative data on the use of the main parts of speech in speeches of politicians, it can be seen that their percentage ratio is uniform. Both female and male politicians equally use parts of speech in their pre-election appeals. Abstract nouns are also used almost identically in the speeches of politicians. Their use serves, on the one hand, to the phenomenon of the euphemism, when it is necessary to disguise the "objectionable" (for one reason or another) information, on the other, enhances the emotional colouring of speech. This is a very clear feature of the political media discourse.

The use of lexical units of language is different. A certain set and their quantitative composition is not a gender-related feature of the analysis of the speeches of political leaders.

In their political speeches, state leaders often use terms that characterize their professional activities.

H. Clinton uses such words as an issue, Senator, the global economy, while B. Obama's speech is full of such terms as revolution, slavery, depression, civil rights.

This method has a positive impact on the image of the political dialogue participants. On the one hand, it is a sign of professionalism and literacy of the speaker. On the other hand, is shows his desire and ability to present the necessary information clearly and intelligibly.

In addition, Obama uses spoken elements in his speech:

to make a huck (earn some money);

childish things (children's problems);

a kid (a child);

Do you wanna...? (Do you want to...?);

to get stuck with the bills (to be unable to pay the bills).

Men in their speeches are less emotional. A striking example is the analysis of Obama's political speeches.

The analysis of the use of syntactic units in speech acts of English-speaking political leaders shows that these are gender-based unmarked types of use of syntactic connection in sentences, as well as types of sentences for the purpose of utterance. In the political dialogue, simple and complex sentences are used in approximately the same way. As a confirmation of their point of view, politicians often use complex sentences in their speech, indicating their ability to logically build their speech and establish the degree of compliance, adequacy between the information request and the expected response. A striking feature of political speech is the use of introductory words. In texts they bear a certain semantic load-aim at the correct perception of the text (first, the second thing, finally), draw their attention to the most important thing (from the point of view of the speaker). The use of syntactic units is gender-specific.

XLinguae, Volume 11, Issue 2, April 2018, ISSN 1337-8384, eISSN 2453-711X 
B. Obama's speeches are characterized by a logical presentation of the material, and H. Clinton's - emotional presentation of the facts using the psychological characteristics inherent in the female sex.

Thus, the distinctive feature of political communication is one of the reasons for poorly expressed gender marking on the syntactic level of the language.

The openness and official character of political speeches (pre-election programs, notes, appeals, statements), features of the social and legal status of political leaders oblige them to fulfill certain norms and rules of communicative behavior.

The speeches of politicians abound in a variety of stylistic means. Thanks to them, the speech of political leaders is very bright, rich, and beautiful. When they are used, the function of influencing the audience is realized, influencing the adoption of those decisions that are beneficial to the speaker, thus the set agitation and propaganda tasks are carried out.

Using special syntactic constructions intended for the syntactic form of speech, the politician realizes one more function, namely, a pragmatic one. It regulates and coordinates the behavior and activities of participants in political communication. The speaker either encourages the audience to perform an action, prohibits or condemns any actions. From the point of view of the variety of ways of constructing simple and complex sentences, the ability to use words and phrases correctly, making up utterances from them, a large number in the speeches of H. Clinton and, B. Obama belong to repetitions. In political speeches, the leaders mentioned above use such stylistic figures and compositional techniques as anaphora and parallelism. They are intended to enhance the expressiveness of speech of participants in the political dialogue. Repetition of speech phenomena, such as words, sounds, stanzas or locutions located in the initial parts of the flow of speech, the variability of their order are not gender marked. This is explained by the fact that they are used, first, to create the necessary atmosphere of the communication situation, for the convenience of delivering the necessary information to the audience. Both men and women use this technique. To enhance the meaning and effect of the speech, female politicians often use ellipsis (i.e., deliberate skipping of nonessential words in a sentence without distorting the meaning). It characterizes speech as a conversational style of communication. As a result, there is the psychological impact on those present. The speaker reveals his psychological qualities: a sense of compassion and empathy for others. The analysis of the empirical study of public statements (their linguistic level) allows us to formulate the following conclusion. Initially politics is considered to be the sphere of activity of the male part of the population, H. Clinton (2017), perhaps at a subconscious level (from the point of view of psychology), avoiding inspiration and impressionability, is often characterized by purposefulness and rationality of her actions and speeches. The study and analysis of the speech aspect is considered at a communicative-pragmatic level. Gender conditioning clearly manifests itself at the level of implementation of the tactic of solidarity (characteristic of H. Clinton). It uses primarily different ways and techniques to establish contact with the audience. B. Obama uses an artistic technique, consisting in reviewing the events of the past.

The remaining tactics considered (in this qualification work) indicate the destruction of traditional stereotypes of gender marking of the communicative-pragmatic level of political texts.

The main goal for a female politician is an attempt to prove her high level of professionalism. Enthusiasm and excitement are the distinguishing features of political appeals by B. Obama.

Thus, analyzing speeches in political pre-election debates, we can say that gender markers at the language levels are erased, and sometimes disappear. The boundaries between "male" and "female" begin to disappear. This is due, first, to the peculiarities of the socio- and linguacultural situation. 
Proceeding from the foregoing, we can say that at the communicative-pragmatic level, gender conditioning consists in a certain complex of speech methods, techniques and methods. However, often it is temporary and not always consistent. The analysis of the research material opens up great opportunities for studying the features of political media discourse of politicians depending on the biological sex and physiological characteristics.

\section{Conclusion}

The common linguistic features of masculine and feminine political media discourse include frequent use of the superlative and comparative degrees of adjectives; active voice prevailing over passive, the low frequency of compound independent clauses; active use of stylistic devices. Masculine political media discourse is characterized by the predominance of negatively colored lexical units, the frequent use of words with negative prefixes, the variety of linking words. Feminine political media discourse is marked by the high frequency of words denoting different emotional states, the use of expressive phrases, the use of words with a modal meaning, expressing obligation, doubt, uncertainty, probability.

\section{Bibliographic references}

ALBRIGHT, M. 2000. Speech by Secretary of State Madeleine K. Albright, Tashkent, Uzbekistan. 17.04.2000. Available online: http://www.friendspartners.org/ccsi/resource/albright.htm

BARANOV, A.N. 2003. Politicheskaya metaforika publicisticheskogo teksta: Vozmozhnosti lingvisticheskogo monitoringa. Moskva: Izd-vo Moskovskogo un-ta. ISBN 5-211-04812-1

BLAIR, T. 1998. Address to Irish Parliament. 26.11.1998. URL: http://www.historyplace.com/speeches/blair.htm

CLINTON, H. 2010. Hillary Clinton. Interview with Vladimir Pozner of First Channel Television. 22.03.2010. Available online: http://pozneronline.ru/2014/12/13038/

CLINTON, H. 2015. Full Text of Hillary Clinton's Presidential Campaign Launch Speech. In: The Fiscal Times. 13.06.2015. Available online: http://www.thefiscaltimes.com/2015/06/13/Full-Text-Hillary-Clinton-s-PresidentialCampaign-Launch-Speech

CLINTON, H. 2017. I still believe Trump is 'a clear and present danger to America'. In: Yahoo News Video. 13.09.2017. Available online: https://www.yahoo.com/news/clinton-still-believe-trump-clear-213547301.html GERASIMENKO, N.A. 2002. Informaciya i fascinaciya v politicheskom diskurse. Moscow: Dialog-MGU. ISBN 5-89209-017-5

GULINOV, D.YU. - ZHELTUKHINA, M.R. - SHESTAK, L.A. - SLYSHKIN, G.G. - KATERMINA, V.V. - CHERVYAKOVA, L.D. 2018. Modern Language Policy: Specifics of Formation and Development of the French Vertical. In: Modern Journal of Language Teaching Methods, vol. 8, n. 2, pp. 159-173. ISSN: 2251-6204

HEUBOECK, A. 2009. Some Aspects of Coherence, Genre and Rhetorical Structure - and Their Integration in a Generic Model of Text. In: Language Studies Working Papers, vol. 1, pp. 35-45. ISSN 2040-3461

ISSERS, O.S. 2008. Kommunikativnyje strategii I taktiki russkoj rechi. Moscow: Editorial URSS. ISBN 978-5-382-00698-7.

JACOBSON, R. 2000. Linguistics and Poetics. In: The Routledge Language and Cultural Theory Reader. London. New York: Routlenge. ISBN 0-415-18680-3

JAMIESON, K.H. - CAMPBELL, K.K. 1997. The Interplay of Influence: News, Advertising, Politics and Mass Media. Belmont: Wadsworth Publishing Company. ISBN 9780534533649. 
LEVINSON, S.C. 1983. Pragmatics. Cambridge: Cambridge University Press. ISBN 978-0521294140

MANN, W.C. - MATTHIESSEN, CH.M. - THOMPSON, S.A. 1992. Rhetorical Structure Theory and Text Analysis. In: Discourse Description. Amsterdam: John Benjamins. ISBN 213/ 822-1511.

MARCU, D. 1996. Building up Rhetorical Structure Trees. Portland: Oregonian Publishing. ISBN 978-0-262-51091-2.

MCCAIN, J. 2008. John McCain's Acceptance Speech. In: The New York Times. Available online: https://www.nytimes.com/elections/2008/president/conventions/videos/transcripts/20080904_MCCAIN_SPEECH.html

MEYERS, H. 2009. Tony Blair. Doctrine of the International Community: 10 Years Later. In: Yale Journal of International Affairs, vol. 1, pp. 5-14. ISSN 1936-2641.

OBAMA, B. 2008. Barack Obama's Acceptance Speech. In: The New York Times. 28.08.2008. Available online: http://www.nytimes.com/2008/08/28/us/politics/28textobama.html

OBAMA, B. 2009a. Inaugural Speech. 22.01.2009. Available online: https://greatspeeches.wordpress.com/2009/01/20/barack-obama-inaugural-speechjanuary-20-2009/

OBAMA, B. 2009b. Transcript: Obama's Speech Against the Iraq War. In: NPR. 20.01.2009. Available online: https://www.npr.org/templates/story/story.php?storyId=99591469

OLYANICH, A.V. 2007. Prezentatsionnaya teoriya diskursa. Moscow: Gnosis. ISBN 5-7333-0184-8.

PAVLIC, J.V. 2009. New Media Journalism. Los Angeles: William F. Eadie. ISBN 1412950309.

POLITICALLY SPEAKING. 1998. A Worldwide Examination of Language Used in the Public Sphere. Westport: Praeger Publishers. ISBN 0-275-96122-2.

POPOVA, T.G. 2014. Metafora v konceptual'noj sisteme. In: YAzyki i kul'tury v sovremennom mire. Materialy XI mezhdunarodnoj konferencii. Parizh: Nacional'noe obshchestvo prikladnoj lingvistiki (NOPriL), Rossijskij centr nauki i kul'tury v Parizhe, Postoyannoe predstavitel'stvo Rossii pri YUNESKO, Posol'stvo Rossijskoj Federacii vo Franci, pp. 299-303. ISBN 978-5-9905599-1-2.

SAUSHEVA, E.V. 2017. Rol' metafory v kommunikativnom processe. In: Vestnik Kostromskogo gosudarstvennogo universiteta: Nauchno-metodicheskij zhurnal, vol. 4, n. 23, pp. 234-235. ISSN 1998-0817.

SHEIGAL, E.I. 2003. Semiotika politicheskogo diskursa. Moscow: Gnozis. ISBN 594244-004-2.

SURIKOVA, T.I. 2017. Za chto termin priznan lukavym? In: Politicheskaya lingvistika, vol. 2, n. 62, pp. 110-115. ISSN 1999-2629.

TARDE, G. 1969. On Communication and Social Influence. Chicago: University of Chicago Press. ISBN 0226789713.

THATCHER, M. 1991. House of Commons Speech. Available online: https://www.margaretthatcher.org/document/108291

THATCHER, M. 1993. House of Commons Speech. Available online: https://www.margaretthatcher.org/document/108314

THOMPSON, J. 1995. The Media and Modernity: A Social Theory of the Media. Cambridge: Polity Press. ISBN: 9780804726795.

WITOSH, B. 2005. Linguistic Study of Genres. Problematic Aspects. Katowice: Publisher University of Silesia. ISBN 83-226-1495-0

YUDINA, T.V. 2001. Teoriya obshchestvenno-politicheskoj rechi. Moscow: Flinta. ISBN 5-211-04415-0 
YUSUPOVA, R.R. - TEPLYH, R.R. 2017. Demonizaciya «plohih» politicheskih liderov kak instrument informacionnoj vojny. In: Politicheskaya lingvistika, vol. 5, n. 65, pp. 163- 167. ISSN 1999-2629.

ZHELTUKHINA, M.R. - BIRYUKOVA, E.V. - GERASIMOVA, S.A. - REPINA, E.A. - KLYOSTER, A.M. - KOMLEVA, L.A. 2017a. Modern Media Advertising: Effective Directions of Influence in Business and Political Communication. In: Man in India, vol. 97, n. 14, pp. 207-215. ISSN: 0025-1569.

ZHELTUKHINA, M.R. - MOUZYKANT, V.L. - BARABASH, V.V. PONOMARENKO, E.B. - MOROZOVA, E.V. - MORI, S. 2017b. Russian and Japanese Younger Generations in Search for a New Media Product. In: Man In India, vol. 97, n. 3, pp. 223-236. ISSN: 0025-1569.

ZHELTUKHINA, M.R. 2003. Tropologicheskaya suggestivnost' massmedial'nogo diskursa: o specifike rechevogo vozdejstviya tropov v yazyke SMI. Moscow: IYA RAN. ISBN 5-88234-568-5.

Words: 5541

Characters: 37683 (20,94 standard pages)

Prof. Tatyana G. Popova, PhD

Associate Prof. Yelena V. Sausheva, PhD

Faculty of Foreign Languages

Military University of the Ministry of Defense of the Russian Federation

14 B. Sadovaya

123001 Moscow

Russia

tatyana_27@mail.ru

spring25@mail.ru

Associate Prof. Tatyana I. Surikova, $\mathrm{PhD}$

Faculty of Journalism

M.V. Lomonosov Moscow State University

9/1 Mokhovaya

125009 Moscow

Russia

surikova_t@mail.ru

Associate Prof. Rozaliya R. Yusupova, PhD

Institute of Law

Bashkir State University

131 Dostoyevsky

450005 Ufa

Russia

rozaliya-yusupova@yandex.ru

Associate Prof. Anna I. Dzyubenko, PhD

Institute of Philology, Journalism and Cross-Cultural Communication

Southern Federal University

93 Universitetsky Lane

344006 Rostov-on-Don

Russia

dzyubenkoanna@gmail.com

XLinguae, Volume 11, Issue 2, April 2018, ISSN 1337-8384, eISSN 2453-711X 